\title{
Analysis of Retailers'Communication Approaches in Sustainability and Social Responsibility Reports
}

\author{
Mohamed MEJRI (Corresponding author) \\ University of Littoral Côte d'Opale \\ 21 Quai de la Citadelle, B.P. 35528, 59383 Dunkerque Cedex1, France \\ E-mail: mohamed.mejri@univ-littoral.fr
}

Daniel DE WOLF

University of Littoral Côte d'Opale

189 Boulevard Maurice Schumman, BP 5526, 59379 Dunkerque Cedex1, France

E-mail: daniel.dewolf@univ-littoral.fr

\author{
Received: November 21, $2011 \quad$ Accepted: February 29, $2012 \quad$ Published: April 1, 2012 \\ doi:10.5539/ijms.v4n2p30 URL: http://dx.doi.org/10.5539/ijms.v4n2p30
}

\begin{abstract}
Following the emergence of stakeholders' societal awareness, retailers adopted different types of social actions and have recently begun to publish social reports to demonstrate their commitment to sustainability and social responsibility in order to be perceived as good corporate citizens.

The purpose of this paper is to analyze and to discuss approaches adopted by retailers in communicating about their societal commitment through their non-financial reports.

Using a qualitative methodology, we found that these reports are purely informative for some retailers, whereas for others, they are a societal positioning tool allowing retailers to differentiate themselves from competitors.
\end{abstract}

Keywords: Retailing, Sustainable Development, Corporate Social Responsibility, Reporting, Lexical analysis

\section{Introduction}

Retailers are nowadays very large corporations. According to the 2011 Deloitte report, Leaving home: Global Powers of Retailing, the sales of the 250 most powerful global retailers reached 3.76 trillion dollars in 2009, the average size of the Top 250 retailers is about 15.05 billion dollars and the composite compound annual growth rate in retail sales over the period 2004-2009 is 6.1 percent.

Because of their increasing economic weight, the importance of the externalities generated by their activities on society and the environment, and even their influence on the consumers' lifestyle (McGoldrick, 2002), retailers are actually frequently criticized by various stakeholders, especially the mass media and consumer advocacy groups because of their socially irresponsible business practices (Wagner, Bicen and. Hall, 2008).

Consequently, retailers are currently widely interested in sustainable development (SD) and corporate social responsibility (CSR). According to recent reports and research (Brady, Hendry and Kanchwala, 2010; Deloitte, 2009; Girod, 2003; Gunther, 2006) retailers are frequently making an effort to demonstrate their environment and social commitment, to be perceived as good corporate citizens (Gunther, 2006).

Particularly, retailers are increasingly keen to communicate their commitment to CSR to their stakeholders (Jones, Comfort and Hillier, 2005). For many years, and like firms from other sectors, retailers have begun to communicate their societal performance by using a variety of media (brochures, Internet, advertising, reports, etc), and the non-financial or SD / CSR report is apparently the main media of communicating with stakeholders.

Assuming that CSR communication and action are interrelated functions (Chaudhri \& Wang, 2007) although it may or may not be an accurate representation of CSR action (Fukukawa \& Moon, 2004), several researchers, interested in analysis of $\mathrm{SD} / \mathrm{CSR}$ retailers strategies, have deliberately chosenthe retailers $\mathrm{SD} / \mathrm{CSR}$ reports as a data source, and most often, the content analysis as a data analysis method (Gregoratti, Hughes and Wrigley, 
2009; Jones, Comfort \& Hillier, 2005; 2006; 2007; Jones et al. 2005; Lee, Fairhurst \& Wesley, 2009; Rana, 2007).

Although this can partially help us to understand how retailers deal with social challenges, literature of discourses analysis shows us that analyzing only the expressed and apparent content of a discourse can be insufficient. Indeed, analysis of other elements of the discourse should help researchers to discover the latent content of the discourse, and then, to deepen our understanding of the retailers' drivers and legitimizing tactics.

As yet, only few researchers have dealt with the retailers' communication approaches (Nielsen and Thomsen, 2007). In the retailing context, to our knowledge, only Gregoratti, Hughes and Wrigley (2009) deal with this issue. The authors have examined, but superficially, the way retailers communicate about their social and sustainable actions and found that the retailers' communication approaches vary substantially.

To contribute to this research field, the purpose of this paper is to analyze and discuss how retailers communicate about their societal actions and initiatives through the SD/CSR reports. Such analysis can help us to discover the tactics adopted by retailers to legitimize their activities and increase their reputation.

To achieve this objective, the paper is organized in four sections. Firstly, a review of literature of SD and CSR in the retailer sector is presented, followed by a description of an analysis method of SD and CSR report in the third section. Then, the results are discussed and finally, the conclusion is presented.

\section{Theoretical Framework}

The last two decades have been marked by the emergence of two concepts that have changed the way businesses operate, namely sustainable development and corporate social responsibility. Both concepts consider that companies do not only have to create value for their shareholders, but also have to bear responsibility for the social and environmental impacts of their activities, and they have to meet the needs of all their stakeholders. The first concept, Sustainable Development has emerged following the publication of the Brundtland Report (UNEP, 1987) and was mediated through the Earth Summit held in June 1992 in Rio de Janeiro. Although, at the beginning the concept was macroeconomic and concerned States, it has been transposed to the economic field and led to the famous "Triple Bottom Line" (Elkington, 1994), which states that the three criteria: social, economic and environmental, have become inseparable in doing business and evaluating business performance.

According to several researchers, the birth of the concept of Corporate Social Responsibility dates back to the fifties and is linked to the publication of the book by Bowen (1953) dealing with the social responsibilities of the businessman. However, it is at the beginning of the twenty-first century that this concept has really emerged on the political, economic and social scenes.

It is surprising that until now, despite the abundance of definitions, there is no common accepted definition and meaning, and operationalizations of the concepts are still in the center of all debates. However, most professionals and scholars believe that these two concepts are linked and specifically consider CSR as a means to achieve SD.

Strateg is (2003) for example, asserts that CSR is the business contribution to SD, while the World Bank (2004) defines CSR simply as "the commitment of businesses to contribute to sustainable economic development, working with employees, their families, the local community, and the whole society to improve the quality of life, in ways that are good for business and good for development".

Without adopting specific definitions, we simply consider, like Van Marrewijk (2003), that sustainability and social responsibility refer today to business voluntary activities -by definition- that demonstrate the consideration of social and environmental issues in business operations and their interactions with their stakeholders.

\subsection{Retailers and the SD/CSR Movement}

Due to their increasing economic weight, the importance of both positive and negative externalities generated by their activities on the society and on the environment, and especially their ability to influence the consumers' lifestyle (McGoldrick, 2002), retailers are currently at the heart of the movement of SD \& CSR. This has accelerated their appropriation of these concepts and led them to develop actions to demonstrate their social commitment.

The 2009 Deloitte's report, Feeling the squeeze- Global Powers of Retailing (Deloitte, 2009) indicates that, from the 250 most powerful global retailers, two-thirds of them have adopted one several principles of CSR.

A more recent report, published in 2010 (Brady, Hendry and Kanchwala, 2010), shows that in general retailers (specifically the biggest ones) are serious about improving their environmental and social performances and that 
they are putting policies, management systems and programs in place to drive higher environmental and social performance in their own organizations and across their supply chains.

Retailers have begun to consider CSR strategies as a vital element of their strategies (Girod, 2003) and to make an effort to demonstrate their socially responsible behaviors to be perceived as good corporate citizens (Gunther,2006) and to devote, in this respect, a lot of resources in order to improve their images (Gupta \& Pirsh, 2008). Some researchers even argue that retailers are more active in the areas of SD / CSR than firms in other sectors (Lernerand Fryxell, 1988).

As for factors driving retailers to develop socially responsible actions, the increased public criticism on the various socially "irresponsible" retailers' practices (Wagner, Bicen and. Hall, 2008), especially in industrialized countries, is often mentioned. This criticism comes from various stakeholders such as governments (through regulation), NGOs, media, investors, financial markets and consumers. Some researchers claim that, nowadays, pressure from consumers is predominant in driving retailers to develop socially responsible actions (Piacentini, McFadyen, and Eadie, 2000).

Indeed, in many industrialized countries, it has been shown that consumers expect today some form of CSR from retailers (Dawson, 2000), and pay great attention, not only to traditional components of marketing (product, price, services ...), but also to the ways retailers are executing their marketing plans within the greater societal network (Gupta \& Pirsch,2008).Some researchers have also demonstrated that the concept of responsibility is becoming a shopping driver (Arnold, Handelman and Tigert, 1996; Gupta \& Pirsch, 2008, Handelman and Arnold, 1999; Oppewal, Alexander and Sullivan, 2006, Pan et al., 2010).

Handelman and Arnold (1999) have shown that consumers extend other forms of support for the retailer for its socially responsible actions by indicating a greater intention to shop at CSR-motivated stores or by communicating positively about the store (through word of mouth), while Gupta \& Pirsch (2008) and Arnold, Handelman and Tigert (1996) have found that adopting a CSR approach by stores leads to customer satisfaction and a greater loyalty.

Thomas et al. (2002) have shown that consumers respond negatively to "unethical" retailers' actions by significantly lowering their ethical assessments of the store and their satisfaction ratings of the service provided.

Recently, Pan et al. (2010) demonstrated that when retailers' SD actions are perceived and valued, consumers show an emotional connection that is translated into positive attitudes, purchasing intentions and a willingness to recommend the retailers.

Note that the social pressures facing retailers can be perceived, and of course be managed, as a constraint or as a motivation. Some ethical and social proactive retailers (like Marks and Spencer which is well classified inmost rankings of reputation and business ethics) could benefit economically and improved their reputation and brand image.

Furthermore, some researchers believe that the societal impact of retailers' socially responsible actions has only a limited impact on consumers (Oppewal, Alexander and Sullivan, 2006), while others argue that, even assuming that such actions produce effects on consumers, consumer attitudes toward CSR initiatives are complex (Brown and Dacin, 1997; Sen and Bhattacharya,2001) and become difficult to understand.

\subsection{Areas of Retailers' Social Actions}

Researchers demonstrated that retailers have adopted several types of social actions to express their commitment to $\mathrm{SD} / \mathrm{CSR}$, but generally on specific areas.

For example, Marques et al. (2010) found that Brazilian supermarkets focused on strict regulations and labor laws and did not address the development of broader actions or social projects. Brady, Hendry and Kanchwala, (2010) argued that retailers focused most on climate change, ethical sourcing and supply chain impacts of products and argue that this is likely due to customer demand for actions in these areas, as well as the retailers' effort to reduce their business risk and costs.

To take in consideration the specificity of retailers' societal actions, some researchers have developed a specific retailers SD/CSR framework. Indeed, and while some authors (such as Lee, Fairhurst and Wesley, 2009) have adopted the four-part model of Carroll (1991) which is the dominant model of CSR (Note 1), other researchers go further and suggest other models (Anselmsson and Johansson, 2007; Brashear et al., 2008; Sands and Minahan, 2008; Wagner, Bicen and. Hall, 2008). 
Sands and Minahan (2008) found that, for a retail supermarket, economic corporate behaviors were not first and foremost for customers. The authors also identified two additional categories as constituting CSR, namely supply chain management and providing customer value.

Anselmsson \& Johansson (2007) propose a three-dimensional model which is very different from Carroll's model (1991). The three dimensions they identified were respectively called product responsibility, human responsibility and environmental responsibility. Brashear et al. (2008) proposed a conceptual model that focuses on retailing business practices across the supply chain from the supplier side (local suppliers, global suppliers, manufacturers) to the buyer side (consumers, social welfare); and among the internal stakeholders(shareholders, employees, directors) and external stakeholders (society, environment, community).

Finally, the original work of Wagner, Bicen and Hall (2008), focused on the concept of retailers' social "irresponsibility" resulted in fourteen factors arising from consumers' perception. These factors are the natural environment, local businesses, foreign economies, local employment, societal rules, employees' benefits, employee wages, local working conditions, employee discrimination, foreign labor, sales practices, dishonesty, offensive materials and pricing policies.

Retailers have also understood that only adopting socially responsible actions and initiatives without communicating them will be ineffective and even irresponsible, as it is asserted by some authors (McWilliams \& Siegel, 2001). Consequently, retailers have begun for many years to communicate their societal performance by using a variety of media (such as brochures, Internet, advertising, etc.) and SD / CSR report is apparently the main medium of communication with stakeholders (Gray et al., 1996). Indeed, according to some authors such as Ferns, Emelianova and Sethi (2008), the number of companies which are publishing SD / CSR reports, is nowadays increasingly important.

\subsection{Analysis Methodologies of the Retailers' SD/CSR Strategies}

To study the retailers' societal strategies, researchers used various methodological approaches. Some researchers like Girod (2003) and Brashear \& al. (2008) have adopted a purely conceptual approach, others interviewed stakeholders. For example, Erol et al., (2009) interviewed the managers of 20 retailers; Anselmsson and Johansson (2007) and Wagner, Bicen and. Hall, (2008) interviewed in a first qualitative stage a sample of people, and then through a second quantitative stage, conducted an investigation on larger samples of people. However, most researchers have analyzed retailers' societal strategies through content analysis of SD / CSR reports. Sometimes, some researchers used simultaneously other methodological tools such as participant observation, surveys, interviews or analysis of newspapers. It is however interesting to note here that the reports analysis has often focused only on the apparent content and through a simple manual content analysis Jones, Comfort \&Hillier (2005) conducted a content analysis of CSR reports and information communicated on the website of the 10 largest UK retailers. For coding the data, four categories were used: environment, supply, customers and community. In a second research, Jones et al. (2005) studied the CSR reports and websites of 20 leading UK retailers. In 2006, Jones, Comfort \& Hillier have adopted a similar procedure. The data were collected from CSR reports and information posted on the World Wide Web by the UK's top ten food retailers and from a simple inspection and information collection survey conducted in the largest stores in the UK. More recently, these authors conducted a content analysis of CSR reports and information posted on the World Wide Web by the UK's top ten food retailers, followed by participant observation in their largest branch stores in one medium-sized English town (Jones, Comfort \&Hillier, 2007). Gregoratti, Hughes and Wrigley (2009) analyzed the content of CSR reports, websites and financial reports of a sample of 20 transnational retailers, while Rana (2007) conducted a case study of Tesco through a content analysis of annual reports posted between 2002 and 2007 as well as a numerous press articles (about 150 pages on the BBC, over 7000 articles in the Guardian). Finally, Lee, Fairhurst \& Wesley (2009) conducted a content analysis of websites of the 100 largest U.S. retailers.

Let's note that researchers have usually only focused on the expressed content of the SD/CSR report, and that is insufficient. Literature of discourse analysis shows us that there are other elements of the discourse which should help researchers to discover the latent content of the discourse (enunciations, argumentative strategies, narrative/descriptive/argumentative style), and then, to understand the speaker. As yet, to our knowledge, only Gregoratti, Hughes and Wrigley (2009) have dealt with the retailers' communication approaches. The authors have examined, but superficially, the way the retailers communicate about their social actions and found that their approaches vary substantially. While some retailers rely on quantitative evidence, others rely on case study and illustrative material. Also, all retailers' reports primarily narrate cases of best practice in CR adopted at home, and occasionally, in developing host economies, but bad practice issues are rarely acknowledged. 


\section{Method}

\subsection{Data Collection}

The data used in this research were collected in the late 2008 from the English version of SD/CSR reports of a sample of thirteen retailers from different countries namely Best Buy \& Wal Mart (USA), Carrefour \& Casino (France), Kingfisher, Marks and Spencer, Sainsburrys, Morissons \& Tesco (UK), Coop (Switzerland), Delhaize (Belgium), Ahold (Netherlands) \& Metro (Germany) (Note 2).

Of the thirteen reports analyzed, six refer explicitly to the concept of SD; six refer to the concept of CSR, while the theme of the Marks and Spencers report is not clear. From the title, the report covers the environmental, social and ethical performance. The number of pages of these reports varies between 24 pages (Morrisons \& Best Buy) and 116 pages (Sainsburys) with an average on the entire sample of 61 pages. All reports are colorful and contain several images and illustrative photos, except the Best Buy report and to a lower degree the Wal Mart report. Ahold and Tesco reports, however, are those which contain the most pictures. Finally, the global corpus (from all reports) is sufficiently large, it has 62535 words, an average of 4811 words per report.

\subsection{Analysis Method}

The large size of the corpus makes content analysis very heavy and, therefore, may make interpretation difficult or impossible, that's why we have preferred lexical analysis to the content analysis. The basic idea of lexical analysis is to replace the study of the text with the study of the set of words which makeup the text (Gavard-Perret \& Moscorola, 1996). Lexical analysis changes then the focus of content analysis from the reading of the text to the reading of its lexical substitutes and thus can considerably speed up the knowledge process (Moscarola, 2002). The user supposes that each word is an indicator of discourse and acts as the track of cognitive models of the author's text (Moscarola, 2002).

We used Sphinx-Lexica and Tropes softwares and the data analysis was conducted in two stages as recommended by Gavard-Perret and Moscarola (1996). The first stage aimed to study the content of the report or what the report says, while the second stage aimed to study the various models of enunciation adopted by the reports. According to Gavard-Perret and Moscarola (1996), the analysis of enunciation needs to answer the question "how are reports formulated?", while for Igalens (2007), who analyses non-financial reports of French CAC 40 companies, the study of enunciation consists mainly in identifying who speaks in a report. Thus, and to study the content, the reduced lexis of words has been established. This lexis is obtained from the global lexis after the suppression of tool-words (Gavard-Perret and Moscarola, 1996), which are words without special meaning (such as and, such, then ...). However, given the large size of the lexis (6 214 words), we have grouped the words according to lexical fields (themes) to which they belong. We therefore created 18 dictionaries (see Table 1), each representing a particular theme. Subsequently, the distribution of frequencies of occurrence of each theme was established, which is the sum of the frequencies of all words that compose it. To study the enunciative models we established the lexis of verbs, the lexis of adjectives and the lexis of pronouns, then we analyzed the Chief Executive Officer (CEO) letters which are usually at the beginning of each report, testimonials, reference to standards (such as Global Reporting Initiative -GRI) and the report verification or certification process. Note that given the importance of verbs and adjectives lexis, we have adopted the approach advocated by the software Tropes. The verbs used in the reports were classified into three categories, active or action verbs, stative verbs and reflexive verbs (Note 3) while the adjectives were classified into three categories; objective adjectives, subjective adjectives and numeral adjectives (Note 4). Once the verbs and adjectives lexis frequency distribution established, mean differences tests between retailers via the student test $(t)$ have been carried out. As for differences between retailers about the themes raised in the reports, they were analyzed by using the Chi 2 test (see Table 2) and by a correspondence analysis (see Figure 1).

\section{Results}

The lexical analysis focused on a global corpus of 62535 words. The vocabulary is very wide and contains 6214 different words, indicating that on average, every word has been used about 10 times in every report. Due to the large extent of the lexicon obtained, we created 18 dictionaries.

Each of these dictionaries contains a set of words that belong to the same lexical field and evoke a specific theme (Note 5). By themselves, these dictionaries represent nearly two thirds of the whole corpus (3941 words compared to 6214 words).

We also created two nominal variables. The first one was called retailers and admits thirteen categories each representing a retailer, and the second one was called themes, admits 18 categories, each representing a specific theme (Note 6). 
The study of the occurrence distribution of the different lexical fields (Table 1) shows a predominance of the themes "Environment" and "Products / Services" themes. These issues alone account for over half of the vocabulary used $(50,9 \%)$.

Moreover, contrary to what Carroll (1991) stated, retailers communicate only very little about their economic and financial performance. This theme represents only $4.6 \%$ of the used vocabulary. The difference with the reference distribution is very significant. Chi $2=7293.83, \mathrm{df}=17,1-\mathrm{p}=>99.99 \%$.

To investigate the societal positioning of retailers, we crossed the two nominal variables "retailers" and "themes". The dependence between these two variables, as measured by the Chi 2 test is verified. The Chi 2 obtained is very high (Chi $2=2528.79$, df $=204)$ and very significant, since the level of significance of the test tends towards zero. The Phi value is close to 1(0.801) and the significance level associated with it tends towards zero, indicating that the intensity of the relationship is very strong.

The correspondence analysis derived from the contingency table (Table 2), is used to study the relationship between retailers and themes (Figure 1).The two main factors restore nearly $61 \%$ of the total inertia. In addition, retailers located in the peripheries are those who have a distinctive positioning, whereas those located in the center have a non-original positioning.

The map also shows a clear proximity between some retailers and some themes. We can see that Metro and Sainsburys focus on the environment, Wal Mart and Casino are those who communicate the most on health, Tesco highlights ethics, Ahold evokes more than anything else employees, while Marks and Spencer is the one which speaks most about its economic and financial performance.

\subsection{The Use of Verbs in the Reports}

As shown in Table 3, retailers use active verbs more frequently than other categories. These verbs represent on average more than half, but in the Carrefour and Casino reports, they make up about two thirds of the total. These verbs are used in a narrative approach to express or to describe actions carried out in areas related to sustainable development. For example, Carrefour states that it "works to reduce the environmental impact of its stores", while Morrissons says that "the past year, we asked lots of people to talk to us about their experiences and views" and finally Delhaize states proudly that "the group won the 2007 Champion of Diversity Award".

Both Coop and Metro are those which used more stative verbs and then adopted a descriptive approach. These verbs represent about $30 \%$ of all the verbs used in their reports. These verbs are used to express statements or concepts of possession.

Sentences such as "all co-manufacturing companies satisfy high standards in both the efficiency and the quality of work" (Coop) or "At the same time, it is becoming more difficult to produce the respective product range as natural resources are depleted ... "(Metro) illustrate the use of stative verbs in the retailers' reports.

Retailers also used some reflexive or declarative verbs, but Best Buy and Tesco used them most frequently. Such verbs represent almost $25 \%$ in the Best Buy report, while in the Tesco report, they represent almost $20 \%$.

These verbs normally express a statement or a feeling about facts, actions, and objects. They are most often used by retailers to describe the growth of business in a particular area through a comparison over time (in 2007 even though we carried out audits significantly more than the previous year - Tesco), and sometimes a comparison with competitors (In the UK our aim is to stock more local lines than any other retailers - Tesco), or to talk about intentions and future plans of the retailer (we are always seeking new product choices that meet these needs and satisfy everyone in the family - Best Buy).

\subsection{Study of the Adjectives Lexis}

Except in the Wal Mart report, the objective adjectives are most frequent in the reports of retailers $(60 \%$ on average), followed by subjective adjectives and numeral adjectives. Through the use of objective adjectives, retailers want to report objectively their societal actions to make their reports more credible.

The use of numeric arguments is another way to increase the credibility. Figures are in fact more irrefutable arguments of the commitment and the progression of retailers in the economic, social and environmental fields.

Finally, the frequent use of subjective adjectives reflects a "propagandist" aspect of some reports. The speakers sometimes give assessments and express some personal "viewpoints".

The cases of Wal Mart and Carrefour on the one hand, and Coop and Ahold on the other hand, are somewhat typical. The first retailers are those which use more numeral adjectives, while, conversely, Ahold and Coop are retailers that use the least. 
In the Carrefour report, there is a predominance of objective adjectives, special importance of numeral adjectives and very few subjective adjectives. In the Wal Mart report, the numeral adjectives are more frequent and there are very few subjective adjectives.

In contrast, in Ahold and Coop reports, objective adjectives are most frequent. In these reports, these adjectives represent more than two-thirds of all the adjectives, while numeral adjectives represent only $16 \%$ in the Ahold report and $18 \%$ in the Coop report.

\subsection{Using of Pronouns}

Retailers do not use pronouns in the same proportions. The $t$ test comparing the frequency distribution of each pronoun in the reports is always significant at $5 \%$ (see Table 3 ).

Except in Coop and Kingfisher's reports, "we" is by far the most frequently used pronoun, followed by the pronoun "they" and the pronoun "I". The frequency of the pronoun "you" is also remarkable in the Best Buy, Coop and Wal Mart reports.

The predominance of the pronoun "we" is due to the fact that the main speaker always speaks on behalf of the group and naturally uses this pronoun.

Even CEOs most often use the pronoun we and rarely the pronoun "I". Besides some CEOs like Georges Jacobs, Chairman of the Board of Directors of Delhaize or Justin King, Chief Executive Chair of Sainsburry's, have never used the pronoun I and only use the pronoun "we".

As for the pronoun "I", relatively frequent in some retailers' reports (Carrefour, Coop and Sainsburry's), navigation in the text shows that it is most often used by the witnesses. These witnesses even as members of other organizations often express their personal viewpoint and of course use the pronoun "I".

The pronoun "you" is used to appeal to the reader. Through the use of this pronoun, the retailers are looking primarily to involve the reader (We do, and we think you do, too - Best Buy), to create a feeling of proximity in the reader and give him the impression that the retailer speaks directly to him. For example, in the Sainsburrys report, it is mentioned that : "We want our food to taste great as well as being good for you and we work closely with our suppliers to make sure that we have reduce the salt, fat or sugar in our products, we do not compromise the taste and quality our customers want".

Similarly, in the Best Buy report we find this as an illustrative extract: "You might be one of our 140,000 employees. Perhaps you're a customer, or a shareholder. You might be a representative of a community where we do business. You might be one of our business partners, or perhaps you represent an advocacy group. We think there is a very good chance you are more than one of these. You're a stakeholder of ours - you have a vested interest in our 17 businesses. This report is for you".

\subsection{CEO Letter}

All reports begin with the CEO letter, except the Best Buy report, although it uses the GRI guidelines (see table 4). This is probably due to a lack of experience in developing non-financial reports. This report is in fact the 2 nd report of this retailer; its first social report was published in 2007.

Coop and Kingfisher have chosen to present the CEO letter in the form of an interview. The CEO answers to specific and clever questions of, sometimes, a fictional journalist. This gives the illusion of greater spontaneity and creates a feeling of closeness between the leader and the reader, who may feel that the officer replied directly to him (Igalens, 2007).

To study the enunciative positioning of the CEOs, we have studied the way they use the pronouns. As already mentioned, CEOs often use the pronoun "we" and rarely the pronoun "I". Besides, some CEOs like George Jacobs (Delhaize) and Justin King (Sainsburry's) never use "I" and rather use the pronoun "we."

The use of "we" by the CEO is a way to remind the reader that he is the retailer's spokesperson and speaks on behalf of all members of the company and under the powers conferred to him by the shareholders.

For example, Morrisons' Chief Executive Marc Bolland said: "We view sustainable development as integral to the way we do business and as such, it is our 'license to operate". Also, Lee Scott, President and Chief Executive Officer, Wal-Mart Stores, Inc said "We do recognize our opportunity and our responsibility to make a difference in this world for our customers, our shareholders and our associates,.. ".

The CEO also wants to show that the societal actions and projects are a strategic issue for the retailer and therefore all members are involved. 
As for the pronoun "I", it's used by the CEO to build an opinion, to express his personal commitment or to give more weight to some personal ideas, and finally to create a certain proximity to the reader by addressing wishes, thanking him or expressing some appreciation.

To illustrate the use of the pronoun "I" and "You" by the CEOs we refer, firstly to John Rishton (Ahold CEO) who says that: "we are making progress with our company-wide corporate social responsibility (CSR) strategy and initiatives .... I hope you find this report useful and I look forward to updating you on the progress we make this year in next year's report"; and secondly to Jean-Charles Naouri, Chairman and Chief Executive Officer of Casino Group who says "Beyond our stores and the products we sell, we are continuing our efforts to act as a community-minded business with respect to our various stakeholders and, first and foremost, our employees. ... Much remains to be done, but I am very confident in the capacity of our work-force to mobilize and innovate in order to meet the challenges of Sustainable Development".

\subsection{Testimonials}

Testimonials are collected from people inside and/or outside the company and are normally entirely inserted without any modification. Indeed, out of thirteen retailers, seven have included testimonials in their reports (Ahold, Carrefour, Casino, Coop, Delhaize, Kingfisher and Sainsburry's) (see Table 4).Various witnesses were asked by retailers to express their opinions about the company and / or its societal initiatives. Their stories are often less technical (to make it easily understandable by the reader), more subjective (since they are not subject to verification), but authentic. Their aim is often to reinforce or increase the credibility of the ideas presented in the reports. The status and number of witnesses vary from one company to another. Six companies (Ahold, Carrefour, Casino, Delhaize, Kingfisher and Sainsburry's) used internal and external witnesses, while the retailer Coop used only external witnesses. Among the internal witnesses, we can mention members of the management board, director of quality and food safety, vice president of human resources and organizational development, environmental expert, director of corporate responsibility, assistant secretary general of a foundation. As for external witnesses, retailers used NGO representatives (like the general manager of the WWF, the head of the WWF's sustainable fishing program, the senior education officer at the British Nutrition Foundation), a suppliers manager, a primary school teacher ...

\subsection{Standards and Certification of the Reports}

To certify the quality of their reports, and increase their credibility, some retailers refer to SD /CSR standards or social reporting guidelines (especially GRI) and submit their reports to the audit and/or for certification by third party auditors (see table 4). The only exception that we have registered is the case of Casino, which has submitted its report for an internal audit.

Among the thirteen retailers studied, seven cited the GRI standards in their reports (Ahold, Best Buy, Carrefour, Coop, Delhaize, Kingfisher and M \& S). Carrefour also used the Global Compact and the OECD guidelines, while Kingfisher cited the insurance quotes AA1000. As for certification, six reports have been checked and certified through various processes and auditors. Indeed, three reports (Delhaize, Kingfisher and Marks and Spencer) have been subject to audit by a third party. The Casino report was only internally audited, while the Carrefour report has been verified by both internal and external auditors, and finally, Kingfisher has adopted an original process by submitting his report to the audit by a panel of stakeholders. The members of this panel were interviewed on the basis of their personal capacity and not as representatives of their organizations. They were asked to give their comments and reflections on the report and the process of its production. The effective audit of the report was made by external auditors.

\section{Discussion}

Due to the rise of external pressures from multiple stakeholders, retailers are currently asked to demonstrate their involvement in solving social problems. Besides the implementation of effective actions within the economic, social and environmental fields, retailers are now required to communicate their social performance using several tools (public relations, advertising and sponsorship) as well as the SD / CSR report which seems nowadays to be the most used.

Unlike the annual financial report, whose purpose is more specific and limited - to inform shareholders and investors -, the SD / CSR report is less ambitious but more precise. It aims primarily to seduce various stakeholders and to legitimize the activities and even the existence of the retailer.

At first sight, reports seem to be similar or at least having many common elements (the CEO letter, report structure, aesthetic value). However, a deep analysis of the discourse on SD / CSR reveals several dissimilarities 
and leads to admit that the retailers are taking different communication approaches (Gregoratti, Hughes and Wrigley, 2009). This finding incites us to analyze better the retailers' tactics of legitimacy.

To communicate about their social initiatives and performance, retailers often adopt a narrative style, which is embodied in the frequent use of active verbs and objective adjectives. The speaker recounts the achievements of the company and seems to avoid the propaganda speech based on subjective judgments and promises. Some retailers choose a more descriptive style using stative verbs and numeral adjectives. Such retailers attempt to describe their societal achievements and especially the progression of the company in social or environmental fields.

As for the privileged areas, a lexical analysis of the reports shows that, first, the themes of environment and products / services (quality, choice, security ...) remain broadly the two privileged themes for retailers' societal communication. This might be explained by the fact that these are the topics to which the public is more sensitive. Moreover, even if it becomes evident today that every stakeholder seems to be sensitive to different aspects of CSR of the same company (Castaldo, Perrini \& Tencate, 2009), our findings show that each retailer only adopts a specific social positioning by focusing on a particular field (the environment, health, family, employees). This probably reflects a certain desire to differentiate from competitors and shows that retailers pursue specific relational strategies towards their stakeholders by focusing on them more than others.

It is also noteworthy that some stakeholders such as government and media are present only marginally in the SD / CSR retailers' reports. Unlike Carroll (1991), retailers communicate lightly about their financial and economic performance. This shows that this type of report does not appear to be intended for shareholders - who are naturally more interested in economic performance - but rather for other stakeholders. Like many businesses, retailers have chosen today to publish annual financial reports only devoted to communicate financial and economic performance and publish in parallel SD/ CSR reports which focus only on social and environmental performance information.

Furthermore, and due to the problem of credibility (Coope, 2004; Ethicity, 2009) (Note 7) and since they know that public confidence in their business and especially CSR communication contributes largely to their success (Castaldo \& all, 2009), retailers adopt different models of utterance.

Based on the idea that the status and credibility of the speaker are crucial to build up public trust (Ferns, Emelianova and Sethi, 2008), the CEO is often the first speaker in a SD / CSR report. He addresses readers with a message that is often a brief description of objectives, actions and social programs of the retailer and provides them with an idea about its progress in areas related to sustainability and social responsibility.

The role of the CEO's message is not only to give the report credibility with stakeholders but also the opportunity to express and reaffirm the CEO's commitments for good corporate citizenship and socially responsible conduct which could contribute significantly to the overall company image (Ferns, Emelianov and Sethi, 2008).

Although most readers will see the CEO as a spokesperson for the company embodying its values, NGOs are still more skeptical about the credibility of CEO's messages (Ferns, Emelianov and Sethi, 2008) and, therefore, retailers use other speakers as witnesses in their reports.

Through testimonials, the retailers are mostly looking to increase the reports' credibility but also to communicate information that usually cannot be verified by the stakeholders (Schoenenberger, 2000), often more subjective and mostly beyond the examination of auditors. In addition, through testimonials, retailers aim to give the impression that they have established a dialogue with their stakeholders and that the report is the result of a process of dialogue and consultation between the retailer and its stakeholders.

Moreover, retailers wish to be perceived as open to criticism (if there's any) of various stakeholders, and that the report is thus guaranteeing a degree of transparency (Igalens, 2007).

It should be noted that testimonials of people depending directly on the company such as managers (tactics most used by retailers), subsidiaries managers, and even suppliers and other partners can't be considered as purely authentic and objective. Such a testimonial is not really spontaneous but most likely solicited, sorted, formatted and often staged.

Note also that testimonials and/or CEOs' messages are under full control of the retailers and, thus, could be insufficient to increase the credibility of reports and stakeholders' trust. The dissemination of quantitative information, the adoption of CSR recognized standards and reporting (GRI, OECD, Global Compact) and verification of reports by third parties appear to be tools that provide the greatest credibility (Hammond and Miles, 2004). This is because they are more objective, irrefutable and cannot be manipulated by retailers. 
Besides, Tschopp (2005) stated that a social report that is not regulated by standards or external guidelines risks becoming part of a marketing strategy and nothing more, thus not meeting the requirements of investors, lobbyists, NGOs and customers.

Although social reporting has remained voluntary until today, the more socially proactive retailers or those with a weak reputation or even a negative image, do not hesitate to submit their reports to the check and to the auditors' certification. Third party certification is nowadays increasingly required by NGOs, as it is considered as an important mechanism for improving the social and environmental conditions within firms (Hatanaka, Bain \& Busch, 2005).

Finally, analysis of speech retailers through their SD / CSR reports reveals two types of reports. The first category of reports is purely informative (Metro, Morissons, Tesco, Best Buy). These reports generally contain the minimum required information, and do not use tools to increase the credibility of the retailer and the confidence of stakeholders (such as testimonials, standards and certification). Retailers publishing such reports are those not suffering from credibility problems or social reputation or those without a long experience in the domain of social reporting (i.e. Best Buy). The second type of report is devoted to legitimization, a greater level of credibility and improving the social reputation of companies. It uses this connection of different tactics such as testimony from stakeholders, alignment with international reporting standards, certification and approval of the report by auditors or a third party or by a panel of stakeholders (Kingfisher).

\section{Conclusion}

Following the emergence of growing stakeholders' societal awareness, retailers adopted different types of social actions and initiatives to demonstrate their societal commitment.

To communicate about their societal actions and achievements, some retailers have recently begun to publish social reports. These reports are purely informative for some retailers, whereas for others, they are a societal positioning tool allowing retailers to differentiate themselves from competitors as well as a legitimizing and a social reputational tool.

Identification of the report kind could be made through analysis of an enunciative approach adopted by the report speaker which can be appreciated by linguistic tools (verbs, adjectives and pronouns) and by other tactics such as the CEO letter, testimonials, reporting standards and the audit and certification process.

In spite of its originality, since it's among the very rare papers which aim to understand how retailers communicate about sustainability and social responsibility, this paper has two limits. The first limit is the small size of the sample. The second one is linked to the data analysis procedures. Indeed, even if the lexical analysis can help us to quickly discover the content, it would be completed by the use of content analysis and eventually semiology, which could lead to a better understanding of retailers' communication and legitimation tactics.

As a future researches, a comparative study of communication tactics through non-financial reports between high reputational and low reputational retailers can be very useful to understand the way retailers are delivering information to their stakeholders. Finally, consideration of the drivers of communication about SD and CSR can also be very useful for a better understanding of the social communication style of retailers. This requires conducting a survey of leaders and CSR managers.

\section{References}

Anselmsson J., and Johansson U. (2007). Corporate social responsibility and the positioning of grocery brands An exploratory study of retailer and manufacturer brands at point of purchase. International Journal of Retail \& Distribution Management, 35 (10), 835-856. http://dx.doi.org/10.1108/09590550710820702

Arnold, S.J., Handelman, J.M., and Tigert, D.J. (1996). Organizational legitimacy and retail store patronage. Journal of Business Research, 35, 229-39.

Bowen, H. R. (1953). Social Responsibilities of the Businessman. Harper and Brothers, New York, NY.

Brady K., Hendry J., and Kanchwala S. (2010). Retail: a sustainability benchmark. GreenBiz reports, Five Winds International.

http://www.greenbiz.com/business/resaerch/report/2010/04/23/retail-sustainability-benchmark

Brashear et al. (2008). A framework for Social Responsible Retailing (SRR) business practices. Revista de Administração FACES Journal, 7 (2), 11-28.

Brown, T. J., and Dacin, P. A. (1997). The Company and the Product: Corporate Associations and Consumer Product Responses. Journal of Marketing, 61 (1), 68-84. http://dx.doi.org/10.2307/1252190 
Carroll, A.B. (1991). The pyramid of corporate social responsibility: toward the moral management of organizational stakeholders. Business Horizons, 34, 39-48. http://dx.doi.org/10.1016/0007-6813(91)90005-G

Castaldo S., Perrini F., Misani N., \& Tencati A. (2009). The Missing Link between Corporate Social Responsibility and Consumer Trust: The Case of Fair Trade Products. Journal of Business Ethics, 84-115. http://dx.doi.org/10.1007/s10551-008-9669-4

Chaudhri V., and Wang J. (2007). Communicating Corporate Social Responsibility on the Internet: A Case Study of the Top 100 Information Technology Companies in India. Management Communication Quarterly; 21(2); 232-247. http://dx.doi.org/10.1177/0893318907308746

Dawson, J. (2000). Retailing at Century End: Some Challenges for Management Research. The International Review of Retail, Distribution, and Consumer Research. 10(2), 119-148. http://dx.doi.org/10.1080/095939600342325

Deloitte (2011). Leaving home: Global Powers of Retailing. [Online] Available: https://www.deloitte.com/assets/DcomGlobal/LocalAssets/Documents/ConsumerBusiness/GlobPowDELOITTE Jan.pdf

Erol I., Cakar N., Erel D., and Sari R. (2009). Sustainability in the Turkish Retailing Industry. Sustainable Development. 17 (1), 49-67. http://dx.doi.org/10.1002/sd.369

Elkington, J. (1994). Towards the Sustainable Corporation - Win-Win- Win Business Strategies for Sustainable Development. California Management Review, 36, 90-100.

Ferns, Emelianova and Sethi (2008). In His Own Words: The Effectiveness of CEO as Spokesperson on CSR-Sustainability Issues Analysis of Data from the Sethi CSR Monitor. Corporate Reputation Review, 11 (2), 116-129. http://dx.doi.org/10.1057/crr.2008.11

Gavard-Perret M.L., and Moscarola J. (1996). Lexical analysis in Marketing: discovering the contents of the message or recognizing the models of enunciation? French-German Workshop on New Developments and Approaches in Consumer Behavior Research (1996), University of Potsdam, Germany, 40 - 59.

Girod, S. (2003). Branding in European retailing: a corporate social responsibility perspective. European Retail Digest, 38, 1-6.

Gray, R., Owen, D., \& Adams C. (1996).Accounting and Accountability; Changes and Challenges in Corporate Social and Environmental Reporting. Harlow: Prentice Hall Europe.

Gregoratti C., Hughes A., and Wrigley N. (2009). Global Retailers, Global Responsibilities: Towards a New Research Agenda, Paper presented at the ESRC workshop, Global Retailers, Global Responsibilities, Royal Geographical Society, London.

Gunther, M. (2006). The green machine. Fortune, 42-57, August 7.

Gupta S., \& Pirsh J. (2008). The influence of a retailers corporate social responsibility program on re-conceptualizing store image. Journal of Retailing and Consumer Services, 15, 516-526. http://dx.doi.org/10.1016/j.jretconser.2008.02.003

Hammond, K., and Miles, S. (2004). Assessing Quality Assessment of Corporate Social Reporting: UK Perspectives. Accounting Forum, 28, 61-79. http://dx.doi.org/10.1016/j.accfor.2004.04.005

Handelman, J.M., and Arnold, S.J. (1999). The role of marketing actions with a social dimension: appeals to the institutional environment. Journal of Marketing, 63 (3), 33-48. http://dx.doi.org/10.2307/1251774

Hatanaka M., Bain C., and Busch L. (2005). Third-party certification in the global agrifood system. Food Policy, 30, 354-369. http://dx.doi.org/10.1016/j.foodpol.2005.05.006

Igalens J. (2007). L'analyse du discours de la responsabilité sociale de l'entreprise travers les rapports annuels de du développement durable des entreprises françaises du CAC 40. Finance-Contrôle-Stratégie, 10, (2), 129- 155.

Jones P., Comfort D., \& Hillier D. (2005). Corporate social responsibility: a case study of the UKs leading food retailers. British Food Journal, 107(6), 423-435.

Jones P., Comfort D., \& Hillier D. (2006). Healthy eating and the UKs major food retailers: a case study in corporate social responsibility. British Food Journal, 108 (10), 834-848.

Jones P., Comfort D., \& Hillier D. (2007). What's in store? Retail marketing and corporate social responsibility. Marketing Intelligence \& Planning, 25 (1), 17-30. 
Jones P., Comfort D., Hillier D., \& Ian Eastwood (2005). Retailers and sustainable development in the UK. International Journal of Retail \& Distribution Management, 33 (3), 207-214. http://dx.doi.org/10.1108/09590550510588370

Lee, Fairhurst \& Wesley (2009). Corporate Social Responsibility: A Review of the Top 100 US Retailers. Corporate Reputation Review, 12 (2), 140-158. http://dx.doi.org/10.1057/crr.2009.10

Marques F., Sérgio P., Mendonça M., José C., \& Jabbour C. (2010). Social dimension of sustainability in retail: case studies of small and medium Brazilian supermarkets. Social Responsibility Journal, 6 (2), 237 - 25. http://dx.doi.org/10.1108/17471111011051748

McGoldrick, P. (2002). Retail Marketing. Berkshire: McGraw-Hill.

McWilliams A., and Siegel D. (2001). Corporate Social Responsibility: A Theory of the Firm Perspective. Academy of Management Review, 26(1), 117-127. http://dx.doi.org/10.5465/AMR.2001.4011987

Moscarola J. (2002). Contribution of qualitative methods to research in work and organizational psychology. Communication to ISSWOV, VARSAW.

Nielsen A.E., and Thomsen C. (2007). Reporting CSR what and how to say it? Corporate Communications: An International Journal, 12 (1), 25-40.

Oppewal, H., Alexander, A., and Sullivan, P. (2006). Consumer perceptions of corporate social responsibility in town shopping centers and their influence on shopping evaluations. Journal of Retailing \& Consumer Services, 13 (4), 261-74.

Pan Y., Zhao G., \& Li R. (2010). The Influence of Sustainable Development on Development of Retail Store Chains. European Journal of Business and Management, 2(1).

Piacentini, M., MacFadyen, L., \& Eadie, D. (2000). Corporate social responsibility in food retailing. International Journal of Retail \& Distribution Management, 28 (11), 459-469. http://dx.doi.org/10.1108/09590550010356822

Sen, S., and Bhattacharya, C.B. (2001). Does doing good always lead to doing better? Consumer reactions to corporate social responsibility. Journal of Marketing Research, 38 (2), 225-243. http://dx.doi.org/10.1509/jmkr.38.2.225.18838

Schoenberger, K. (2001). Levis Children: Coming to Terms with Human Rights in the Global Marketplace. New York: Grove Press, 304.

Strategis (2003). What is CSR? Available: http://strategis.ic.gc.ca/epic/internet/incsr-rse.nsf/vwGeneratedInterE/h_rs00094e.html.

Tschopp, D.J. (2005). Corporate Social Responsibility: A Comparison between the United States and the European Union. Corporate Social Responsibility and Environmental Management, 12, 55-59. http://dx.doi.org/10.1002/csr.69

Van Marrewijk M. (2003). Concepts and definitions of CSR and corporate sustainability: between agency and communion. Journal of Business Ethics, 44, 95-105. http://dx.doi.org/10.1023/A:1023331212247

Wagner T., Bicen P., and. Hall Z R. (2008). The dark side of retailing: towards a scale of corporate social irresponsibility. International Journal of Retail \& Distribution Management, 36 (2), 124-142. http://dx.doi.org/10.1108/09590550810853075

\section{Notes}

Note 1. Stating that CSR is a four dimensional concept -economic, legal, ethical and philanthropic- respectively representing weightings of 4:3:2:1 according to their importance to the company)

Note 2. According to the Covalence Ethical Ranking's, in 2008 Marks \& Spencer is ranked $4^{\text {th }}$ worldwide and first of the retail sector and as ranked by Fortune in 2008, Sainsburys and Marks and Spencer are among the 100 most sustainable corporations in the world.

Note 3. Active verbs: verbs which are expressing action (do, increase, generate, help, invest), stative verbs are verbs which are expressing states or concepts of possession (include, become, be, receive, have) and reflexive ones are verbs which are expressing statement about facts, actions, people, objects, feelings (must, can, want, ensure ).

Note 4. Objective adjectives are those which show existence or absence of a property (sustainable, corporate, responsible, social, environmental, external, organic, financial, increased); subjective adjectives are those which 
show a judgment on something or emotional reaction (healthy, positive, important, active, varied, most), and numeral adjectives which include numbers.

Note 5. For example, the dictionary "environment" includes the word environment, carbon, CO2, nature, natural, organic, climate, ecological, energy, emissions, environmental, environmentally, green, greenhouse, organic, planet, recycle, recycled, recycling, renewable, water, waste.

Note 6. On the topic of stakeholders, we found that retailers sometimes refer explicitly to various stakeholders such as "customers", "employees", "suppliers", "shareholders", "NGOs" ... and sometimes speak in a general way and use in this context the term "stakeholders".

Note 7. In France for example, according to a recent study (Ethicity, 2009), more than half of French people do not trust the companies and the collapse of trust in large companies is proceeding. Moreover, about three-fourths of French people consider that companies do not give them enough information about the conditions of manufacturing and $61.7 \%$ wish to have information on the impact of environmental labels on products. Finally, $88.2 \%$ of them believe that retailers have a role to play in providing information on products (Ethicity, 2008).

Table 1. Frequency distribution of themes

\begin{tabular}{|l|r|r|}
\hline \multicolumn{1}{|c|}{ themes } & Nb. cit. & Freq. \\
\hline ENVIRONNEMENT & 1163 & $29,5 \%$ \\
\hline PRODUCTS \& SERVICES & 842 & $21,4 \%$ \\
\hline CUSTOMERS & 348 & $8,8 \%$ \\
\hline HEALTH & 282 & $7,2 \%$ \\
\hline COMMUNITY \& SOCIETY & 232 & $5,9 \%$ \\
\hline EMPLOYEES & 229 & $5,8 \%$ \\
\hline ECONOMIC \& FINANCIAL PERFORMANC & 181 & $4,6 \%$ \\
\hline SUPPLIERS & 131 & $3,3 \%$ \\
\hline HUMANITY & 116 & $2,9 \%$ \\
\hline STAKEHOLDERS & 117 & $3,0 \%$ \\
\hline NGOS & 58 & $1,5 \%$ \\
\hline FAMILY & 45 & $1,1 \%$ \\
\hline ETHICS & 75 & $1,9 \%$ \\
\hline SHAREHOLDERS & 39 & $1,0 \%$ \\
\hline GOVERNMENT & 25 & $0,6 \%$ \\
\hline ANIMALS & 22 & $0,6 \%$ \\
\hline INVESTORS & 21 & $0,5 \%$ \\
\hline WOMEN & 15 & $0,4 \%$ \\
\hline TOTAL OBS. & 3941 & $\mathbf{1 0 0} \%$ \\
\hline
\end{tabular}


Table 2. Contingency table (Retailers / Themes)

\begin{tabular}{|c|c|c|c|c|c|c|c|c|c|c|c|c|c|c|c|c|c|c|c|}
\hline & 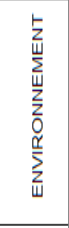 & 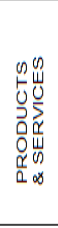 & $\begin{array}{l}\frac{D}{\alpha} \\
\underline{W} \\
\underline{W} \\
0 \\
0 \\
0 \\
0 \\
0 \\
0\end{array}$ & $\begin{array}{l}I \\
E \\
\vec{J} \\
\mathbb{W} \\
I\end{array}$ & 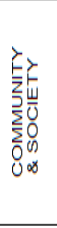 & 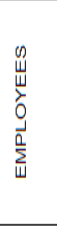 & 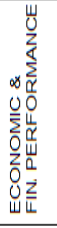 & 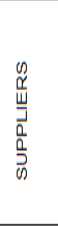 & 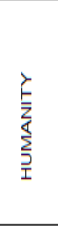 & 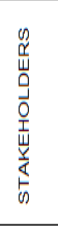 & $\begin{array}{l}n \\
0 \\
0 \\
z\end{array}$ & 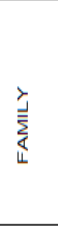 & $\begin{array}{l}\frac{y}{0} \\
\frac{0}{\bar{T}} \\
\frac{1}{4}\end{array}$ & 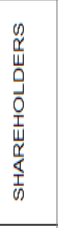 & 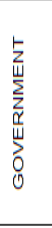 & $\begin{array}{l}09 \\
\frac{1}{4} \\
\frac{2}{2} \\
\frac{2}{4}\end{array}$ & 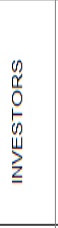 & $\begin{array}{l}\text { Z } \\
\text { z } \\
0 \\
3\end{array}$ & $\begin{array}{l}\frac{a}{\sigma} \\
5 \\
0\end{array}$ \\
\hline Ahold & 16 & 18 & 49 & 18 & 29 & 68 & 13 & 0 & 11 & 4 & 3 & 0 & 3 & 8 & 0 & 0 & 2 & 13 & 255 \\
\hline Best buy & 61 & 25 & 19 & 2 & 19 & 16 & 9 & 16 & 9 & 24 & 17 & 0 & 17 & 13 & 1 & 0 & 0 & 1 & 249 \\
\hline Carrefour & 70 & 120 & 36 & 17 & 4 & 16 & 12 & 11 & 15 & 1 & 3 & 7 & 0 & 0 & 1 & 1 & 0 & 0 & 314 \\
\hline Casino & 75 & 170 & 28 & 84 & 8 & 19 & 7 & 1 & 12 & 12 & 2 & 9 & 0 & 0 & 1 & 0 & 0 & 0 & 428 \\
\hline Coop & 95 & 62 & 15 & 7 & 12 & 11 & 22 & 14 & 5 & 9 & 6 & 5 & 8 & 0 & 3 & 0 & 0 & 0 & 274 \\
\hline Dellhaize & 63 & 46 & 9 & 4 & 20 & 13 & 14 & 5 & 11 & 13 & 1 & 0 & 4 & 1 & 0 & 0 & 3 & 0 & 207 \\
\hline Kingfisher & 156 & 87 & 24 & 17 & 15 & 11 & 15 & 12 & 11 & 8 & 0 & 4 & 2 & 2 & 8 & 7 & 0 & 0 & 379 \\
\hline$M \& S$ & 27 & 81 & 30 & 9 & 23 & 10 & 45 & 15 & 6 & 10 & 4 & 0 & 1 & 4 & 0 & 0 & 8 & 0 & 273 \\
\hline Metro & 204 & 49 & 18 & 5 & 18 & 9 & 2 & 8 & 3 & 7 & 1 & 0 & 4 & 0 & 1 & 1 & 1 & 0 & 331 \\
\hline Morissons & 51 & 65 & 21 & 18 & 10 & 11 & 6 & 16 & 5 & 8 & 6 & 3 & 7 & 0 & 7 & 12 & 3 & 1 & 250 \\
\hline Sainsbutry's & s 266 & 24 & 33 & 0 & 21 & 1 & 5 & 16 & 6 & 0 & 2 & 1 & 0 & 1 & 1 & 1 & 0 & 0 & 378 \\
\hline Tesco & 22 & 14 & 18 & 10 & 13 & 32 & 21 & 6 & 13 & 4 & 5 & 3 & 27 & 10 & 1 & 0 & 0 & 0 & 199 \\
\hline Wal Mart & 57 & 81 & 48 & 91 & 40 & 12 & 10 & 11 & 9 & 17 & 8 & 13 & 2 & 0 & 1 & 0 & 4 & 0 & 404 \\
\hline TOTAL & 1163 & 842 & 348 & 282 & 232 & 229 & 181 & 131 & 116 & 117 & 58 & 45 & 75 & 39 & 25 & 22 & 21 & 15 & 3941 \\
\hline
\end{tabular}

Table 3. Verbs, adjectives and pronouns frequencies distribution

Verhs category

\begin{tabular}{|c|c|c|c|}
\cline { 2 - 4 } \multicolumn{1}{c|}{} & $\begin{array}{c}\text { Factive } \\
\text { verhs }\end{array}$ & $\begin{array}{c}\text { Stative } \\
\text { verhs }\end{array}$ & $\begin{array}{c}\text { Reflexive } \\
\text { verhs }\end{array}$ \\
\hline Best Buy & $\mathbf{7 8 9 ( 0 , 5 2 )}$ & $\mathbf{3 7 8}(0,25)$ & $\mathbf{3 4 8}(0,23)$ \\
\hline Carrefour & $\mathbf{1 9 9 6 ( 0 , 6 3 )}$ & $\mathbf{5 9 4}(0,19)$ & $\mathbf{5 6 4}(0,18)$ \\
\hline Casino & $\mathbf{1 6 6 2 ( 0 , 6 3 )}$ & $\mathbf{5 1 2}(0,20)$ & $\mathbf{4 4 6}(0,17)$ \\
\hline Delhaize & $\mathbf{1 1 8 5}(0,54)$ & $\mathbf{6 2 4}(0,28$ & $\mathbf{3 8 6}(0,18)$ \\
\hline Coop & $\mathbf{1 4 8 3}(0,56)$ & $\mathbf{8 1 0}(0,30)$ & $\mathbf{3 8 8}(0,14)$ \\
\hline Kingfisher & $\mathbf{1 1 7 8}(0,59)$ & $\mathbf{4 9 0}(0,25)$ & $\mathbf{3 1 7}(0,16)$ \\
\hline M \& S & $\mathbf{1 4 1 9}(0,62)$ & $\mathbf{5 3 9}(0,23)$ & $\mathbf{3 4 6}(0,15)$ \\
\hline Metro & $\mathbf{1 3 0 7}(0,54)$ & $\mathbf{7 4 4}(0,30)$ & $\mathbf{3 8 9}(0,16)$ \\
\hline Morrisons & $\mathbf{7 5 5}(0,61)$ & $\mathbf{2 7 6}(0,23)$ & $\mathbf{1 9 3}(0,16)$ \\
\hline Sainshury's & $\mathbf{2 6 4 4}(0,58)$ & $\mathbf{1 3 1 0}(0,28)$ & $\mathbf{6 4 5}(0,14)$ \\
\hline Tesco & $\mathbf{1 9 8 9}(0,56)$ & $\mathbf{8 6 6}(0,24)$ & $\mathbf{7 2 9}(0,20)$ \\
\hline Wal-Mart & $\mathbf{2 3 1 5 ( 0 , 5 4 )}$ & $\mathbf{1 1 7 9}(0,28)$ & $\mathbf{7 5 7}(0,18)$ \\
\hline Ahold & $\mathbf{1 4 0 6 ( 0 , 5 7 )}$ & $\mathbf{6 2 3}(0,25)$ & $\mathbf{4 5 5}(0,18)$ \\
\hline $\boldsymbol{t}$ & 9,959 & 8,375 & 9,843 \\
\hline Sig & 0 & 0 & 0 \\
\hline
\end{tabular}

Adjectives category

\begin{tabular}{|c|c|c|}
\hline $\begin{array}{l}\text { Objective } \\
\text { adjectives }\end{array}$ & $\begin{array}{l}\text { Subjective } \\
\text { adjectives }\end{array}$ & $\begin{array}{l}\text { Numeral } \\
\text { adjectives }\end{array}$ \\
\hline $\mathbf{1 0 3 6}(0,59)$ & $\mathbf{2 9 0}(0,16)$ & $\mathbf{4 3 2}(0,25)$ \\
\hline $\mathbf{2 7 7 4}(0,52)$ & $360(0,07)$ & $\mathbf{2 1 3 9}(0,41)$ \\
\hline $\mathbf{2 0 0 4}(0,57)$ & $\mathbf{3 8 9}(0,11)$ & $\mathbf{1 1 1 0}(0,32)$ \\
\hline $\mathbf{1 6 6 5}(0,57)$ & $391(0,14)$ & $\mathbf{8 2 7}(0,29)$ \\
\hline $\mathbf{1 9 7 6}(0,65)$ & $\mathbf{5 1 0}(0,17)$ & $\mathbf{5 4 5}(0,18)$ \\
\hline $\mathbf{1 2 7 3}(0,61)$ & $\mathbf{1 8 8}(0,09)$ & $\mathbf{6 4 1}(0,30)$ \\
\hline $\mathbf{1 2 3 2}(0,56)$ & $\mathbf{2 7 6}(0,12)$ & $\mathbf{7 1 4}(0,32)$ \\
\hline $\mathbf{1 9 2 9}(0,63)$ & $\mathbf{4 3 4}(0,14)$ & $\mathbf{7 2 3}(0,23)$ \\
\hline $\mathbf{6 9 3}(0,60)$ & $\mathbf{2 1 6}(0,18)$ & $\mathbf{2 5 9}(0,22)$ \\
\hline $\mathbf{2 6 9 2}(0,56)$ & $\mathbf{7 9 9}(0,16)$ & $\mathbf{1 3 7 1}(0,28)$ \\
\hline $\mathbf{1 9 2 6}(0,59)$ & $\mathbf{5 0 3}(0,15)$ & $\mathbf{8 4 6}(0,26)$ \\
\hline $\mathbf{2 3 5 3}(0,42)$ & $\mathbf{4 5 8}(0,08)$ & $\mathbf{2 8 1 4}(0,50)$ \\
\hline $\mathbf{1 6 1 6}(0,65)$ & $\mathbf{4 5 8 ( 0 , 1 9 )}$ & $\mathbf{4 0 1}(0,16)$ \\
\hline 10,364 & 9,287 & 4.827 \\
\hline 0 & 0 & 0 \\
\hline
\end{tabular}

Use of pronouns

\begin{tabular}{|c|c|c|c|c|}
\hline I & you & we & they & He \\
\hline $\mathbf{0}$ & $\mathbf{1 9}$ & $\mathbf{2 1 1}$ & $\mathbf{6 2}$ & $\mathbf{4}$ \\
\hline $\mathbf{1 9}$ & $\mathbf{0}$ & $\mathbf{7 4}$ & $\mathbf{7 1}$ & $\mathbf{0}$ \\
\hline $\mathbf{2}$ & $\mathbf{2}$ & $\mathbf{1 9 6}$ & $\mathbf{1 6}$ & $\mathbf{0}$ \\
\hline $\mathbf{4}$ & $\mathbf{7}$ & $\mathbf{1 8 3}$ & $\mathbf{4 5}$ & $\mathbf{0}$ \\
\hline $\mathbf{4 9}$ & $\mathbf{1 5}$ & $\mathbf{4 6}$ & $\mathbf{5 3}$ & $\mathbf{1 1}$ \\
\hline $\mathbf{0}$ & $\mathbf{1}$ & $\mathbf{1 4}$ & $\mathbf{2 1}$ & $\mathbf{0}$ \\
\hline $\mathbf{0}$ & $\mathbf{6}$ & $\mathbf{4 8 9}$ & $\mathbf{3 1}$ & $\mathbf{0}$ \\
\hline $\mathbf{4}$ & $\mathbf{7}$ & $\mathbf{2 2 5}$ & $\mathbf{5 2}$ & $\mathbf{1}$ \\
\hline $\mathbf{2}$ & $\mathbf{4}$ & $\mathbf{1 6 2}$ & $\mathbf{2 8}$ & $\mathbf{2}$ \\
\hline $\mathbf{2 7}$ & $\mathbf{7}$ & 991 & $\mathbf{1 0 4}$ & $\mathbf{1}$ \\
\hline $\mathbf{9}$ & $\mathbf{2}$ & $\mathbf{6 8 0}$ & $\mathbf{1 2 9}$ & $\mathbf{0}$ \\
\hline $\mathbf{3}$ & $\mathbf{1 0}$ & $\mathbf{7 4 2}$ & $\mathbf{1 3 6}$ & $\mathbf{6}$ \\
\hline $\mathbf{5}$ & $\mathbf{6}$ & $\mathbf{2 8 6}$ & $\mathbf{6 6}$ & $\mathbf{6}$ \\
\hline 2,4 & 4348 & 3,946 & 5,81 & 2,508 \\
\hline 0,033 & 0,001 & 0,002 & 0 & 0,028 \\
\hline
\end{tabular}

Note that the figures between parentheses are percentages. 
Table 4. Indicators of enunciation

\begin{tabular}{|l|c|c|c|c|c|c|}
\hline Retailers & CEO & Internal & External & GRI & $\begin{array}{c}\text { Global } \\
\text { Compact }\end{array}$ & $\begin{array}{c}\text { Report } \\
\text { Auditing }\end{array}$ \\
\hline Ahold & Yes & 8 & 3 & Yes & No & No \\
\hline Best buy & No & - & - & Yes & No & No \\
\hline Carrefour & Yes & 6 & 8 & Yes & Yes & Yes \\
\hline Casino & Yes & 3 & 6 & No & No & Yes \\
\hline Coop & Yes & - & 4 & Yes & No & No \\
\hline Delhaize & Yes & 7 & 1 & Yes & No & Yes \\
\hline Kingfisher & Yes & 2 & - & Yes & No & Yes \\
\hline M \& S & Yes & - & - & Yes & No & Yes \\
\hline Metro & Yes & - & - & No & No & No \\
\hline Sainsburrys & Yes & 4 & 34 & No & No & No \\
\hline Morissons & Yes & - & - & No & No & No \\
\hline Tesco & Yes & - & - & No & No & No \\
\hline Wal Mart & Yes & - & - & No & No & No \\
\hline
\end{tabular}

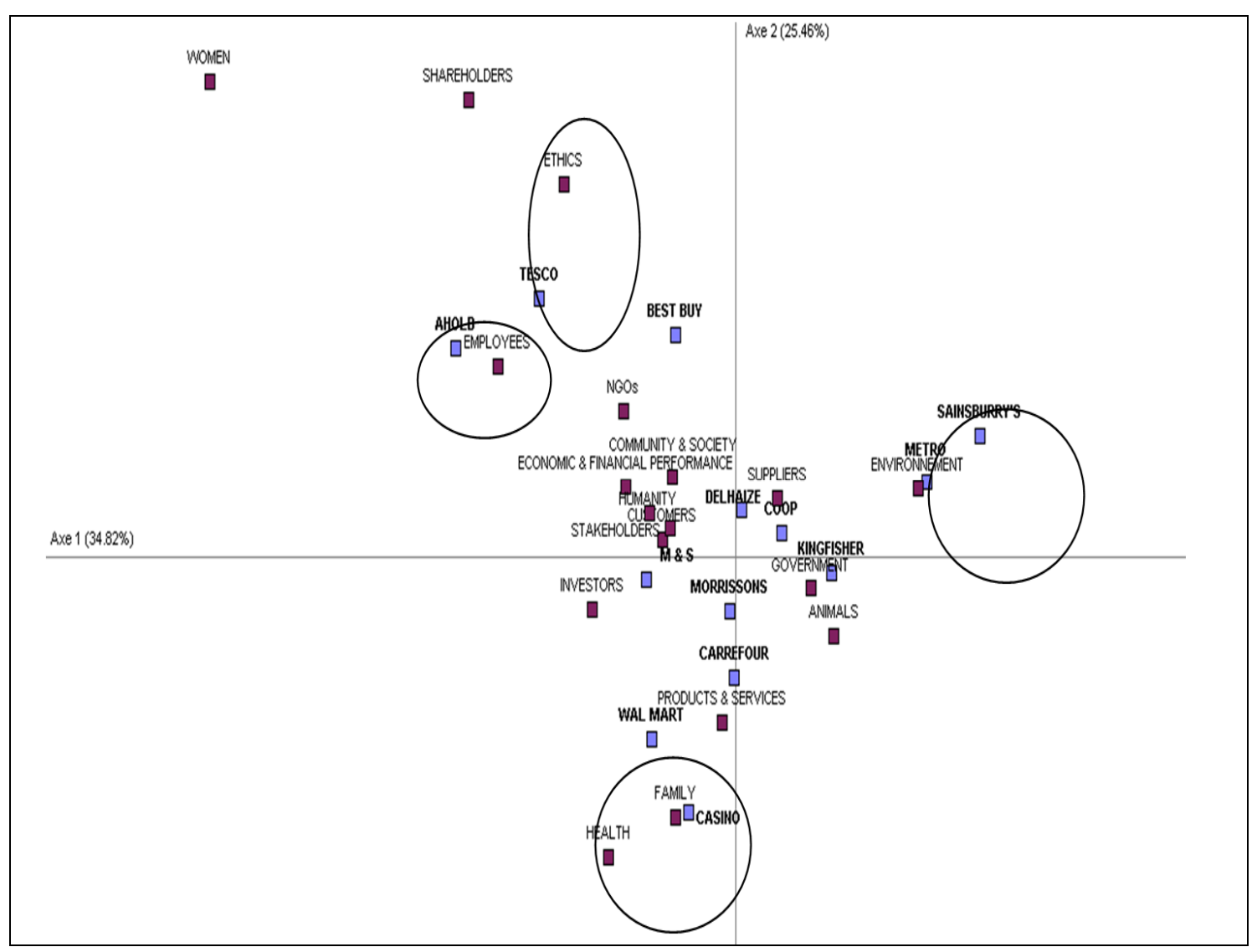

Figure 1. The correspondence map (Retailers / Themes) 